\title{
The Cultural Stigma Attached With Inter-Tribal Marriages Encourages Forced Marriages: Four Selected Case Studies From Rural Sindh
}

\author{
Saeed Ahmed Rid \\ National Institute of Pakistan Studies \\ Quaid-i-Azam University, Islamabad
}

\begin{abstract}
Forced marriages are a common practice in rural areas of Pakistan in general and Sindh in particular. Inhumane customs of honour-killing (karo-kari), child marriage, marriage with Quran and marriage in compensation (sangchatti) which are the worst form of forced marriages still continue to haunt the rural Sindh. Women are the special target of those customs and cultural practices. This research argues that the cultural stigma attached with intertribal marriages and emphasis on consanguineal marriages in rural Sindh is one of the root-causes of the most of the problems related to forced marriages in Sindh. In this regard criminal side of the problem has already been emphasized in human rights reports and research papers but the cultural side has not been studied specially in the context of the rural Sindh. This paper is an attempt to shed a power light on all those issues. Using four selected case studies it is explored that how the taboo attached with intertribal marriages promotes forced Marriages in rural context of Sindh. Moreover, an attempt has also been made to understand the exact legal position regarding forced marriages according to the international Law, local Pakistani law and Shariah law. Above all it is also discussed in this paper that what could be done to decrease the instances of forced marriages among the rural communities of Sindh.
\end{abstract}

Keywords: Forced Marriages, Honour-Killings, Inter-Tribal Marriages, Anti-Women Cultural Practices, Gender Discrimination.

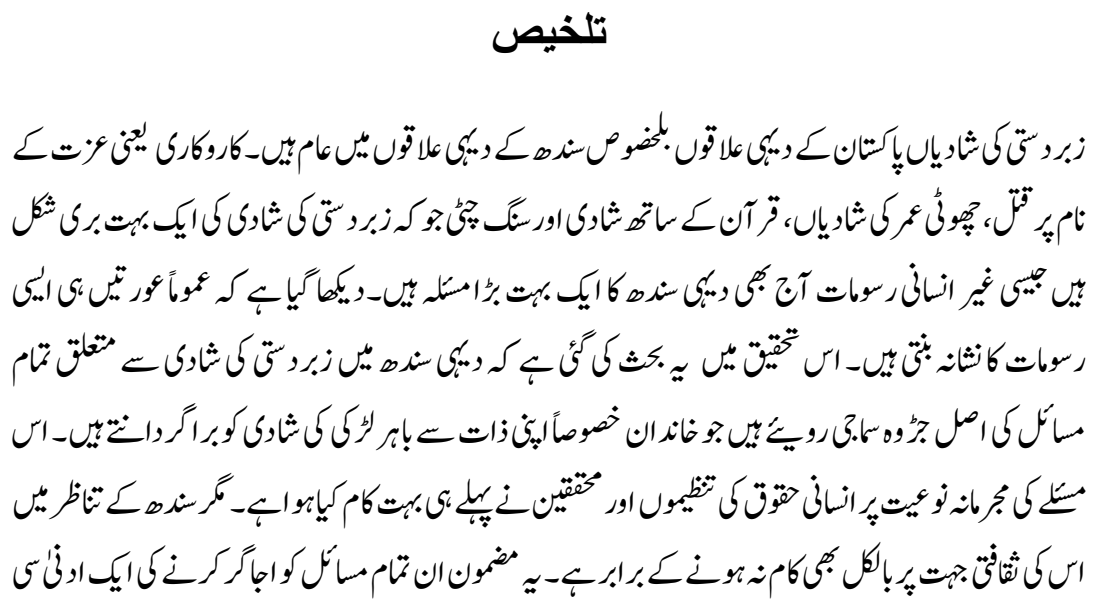




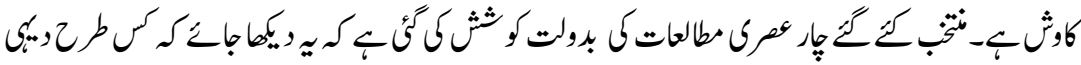

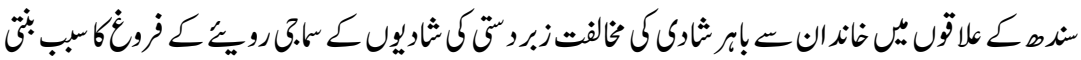

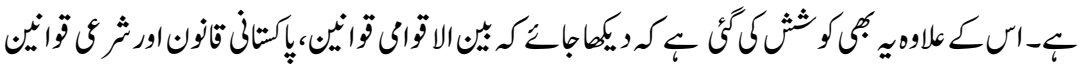

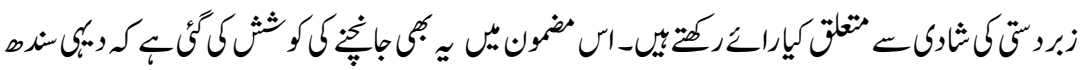

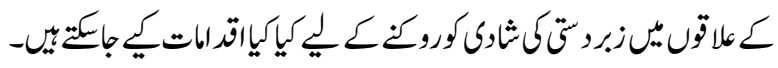

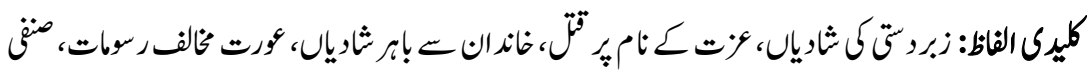

$$
\begin{aligned}
& \text { تغزئن }
\end{aligned}
$$

\section{Introduction}

My three-year-old daughter wanted to have a ritual of danwan which is reserved only for boys in some areas of rural Sindh. The ritual is held when a boy begins to learn how to walk. It involves putting a rope between the child's legs. The rope is then cut by the eldest uncle on the mother's side symbolising a release from all hurdles so that the child can walk and run freely. Why is the ritual specific to boys and why are girls not allowed to have it? The reason is simple: the local people fear that if they have the same ritual for their daughters, they might run away with someone when they grow up. The right to free consent in marriage, especially for girls, is still a distant dream and the concept of marrying for love, taken for granted in Western societies, is still frowned upon in most rural areas in Pakistan.

In Western societies, the issue of the right to marry of free consent only emerges in the context of same-sex marriage. But in the rural areas of Sindh and many other parts of Pakistan where old traditions and local customs are at times even more powerful than the state laws, forced marriages are a routine affair. Especially in the rural culture of Sindh girls are encouraged not to utter a single word in matters of their marriage and are expected to silently accept the choice of the family head (father).

Moreover, the traditional culture in rural areas of Sindh that abhors the inter-tribal marriages becomes a tool for forced marriages in the name of honour. In Sindh tribes and clans are an essential part of the identity of each individual as every individual is known by the name of his/her tribe/clan. Young couples get killed by their tribesmen and family members, if they choose to marry out of tribe of their own free will against the wishes of their family or tribe. Several others live a life of compromise for not resisting the wishes of their parents or tribal leaders. 


\section{Literature Review}

A precise definition of 'forced marriage' and awareness about this crime against humanity has emerged from the academic and legal debates on the topic in UK. The Home office UK in its first study in 2000 defined forced marriage as "any marriage conducted without the valid consent of both parties - may involve coercion, mental abuse, emotional blackmail, and intense family or social pressure" (INTERIGHTS et al., 2000, p.1). Before this the cultural practices of honour-killing, marriage with Quran, Compensation marriage (locally named as sang-chatti, pait-likhi, swara, wanni), exchange marriage (locally named as detileti, watta satta) and child marriage were being raised in the reports of the Human Rights Commission of Pakistan (HRCP) and other NGOs working on the issues of women rights and human rights in Pakistan but they were not termed as forced marriages.

In UK during last decade or so forced marriages in immigrant South Asian and Middle Eastern communities has emerged as an issue of great concern and several studies are conducted in this regard. Among the cases of forced marriages reported in UK according to the unclassified figures of the Forced Marriage Unit (FMU) around $50 \%$ of such cases in UK involve the members of Pakistani community ${ }^{1}$. Since 2000, the Home Office and Foreign and Commonwealth Office UK have commissioned several studies on forced marriages in UK. In first of such study, three NGOs INTERIGHTS in UK, Ain O Sailish Kendra (ASK) in Bangladesh and Shirkat Gah in Pakistan were assigned to assist the Home Office in preparing the strategies for providing the effective redressal to women facing forced marriages in UK (INTERIGHTS et al., 2000). In another Home Office report, Uddin and Ahmed (2000) tried to define the concept of 'forced marriage' and differentiate it from the concept of 'arranged marriage', where full consent of the groom and bride is achieved before the marriage. Then in Home Office (2006) report a study was conducted to assess the risk factors and see the impact of increasing the minimum age for a sponsor, and of leave to enter the UK as a spouse. In 2003 the Foreign and Commonwealth Office and Department of Health in UK prepared a booklet containing guidelines for the social workers working on forced marriages (Foreign and Commonwealth Office and Department of Health, 2003).

Apart from the UK governmental sources, studies done by researchers, scholars and academicians in UK also contributed towards developing a strong case for the legal action against the practice of forced marriages in UK. The studies of Caroll (1998), Hossain (2000), Samad and Eade (2002), Siddiqui (2002), Gangoli et al. (2006) led to the declaration of forced marriages as a civil offence in UK under forced marriage (civil protection) act $2007^{2}$ and then a criminal offence 
punishable up to seven years in prison under Anti-Social Behaviour, Crime and Policing Act 2014. ${ }^{3}$

Just like UK in Pakistan after the Prevention of Anti-Women Practices Act 2011, forced marriage is prohibited and made a criminal offence punishable to maximum seven years and minimum three years imprisonment. ${ }^{4}$ But there are still several substantive and structural gaps in the implementation of Women Protection Act 2011 as identified by Zaman (2014b) in her study of the six selected districts in Pakistan. In Sindh province alone according to the official figures of the Sindh government 1,261 cases of kidnapping women for forced marriages were reported in $2014^{5}$. Especially the cases of Hindu girls being abducted, converted to Islam and then forced into marriages have surged in Sindh in last few years ${ }^{6}$.

Despite the fact that forced marriages are routine affair in rural areas of Pakistan, Zaman's above mentioned research paper is the only direct scholarly research conducted so far on forced marriages in Pakistan (Zaman, 2014b). However, a research report was also prepared by Movement for Solidarity and Peace (MSP) on forced marriages and forced conversions in Christian Community of Pakistan (MSP, 2014). Nonetheless, some valuable academic literature is available on issues which are very close to forced marriages and that also involve some extreme cases of forced marriages. Like on honour-killings in Pakistan Knudsen (2004), Khan (2006) and Chaudhury (2014) have already published their scholarly research which in some cases involves killings of couples marrying of their own choice. Similarly, Chaudhury (2011) wrote a piece on marriage with Quran, Naveed and Butt (2015) on child marriages, Zaman (2011, 2012 and 2014a) on exchange marriages, Khan et al. (2011) on consanguineal marriages and Masihuddin and Minallah (2011) on compensation marriages that also most of the times involve forced marriages.

\section{Significance of the Study}

Hence, we can say literature on forced marriages is available in indirect form in several studies but Zaman (2014b) is so far the only direct study on forced marriages in Pakistan. Moreover, there is no separate scholarly research available on forced marriages in the context of rural Sindh. This study is an attempt to fill this gap in the academic literature and see how cultural ban on inter-tribal marriages in rural Sindh is promoting forced marriages among rural communities in Sindh. For this purpose four case studies are selected from the rural context in Sindh which includes two high profile case studies and two case studies of more common nature which do not get even noticed by the media and the society at large. 


\section{Research Questions and Research Methodology}

The main research question of this study is to explore how the taboo attached with inter-tribal marriages promotes forced Marriages in the rural context of Sindh. To answer this main question the supplementary questions for this study are,

- What is the position of the international Law, local Pakistani law and Shariah law vis-à-vis forced marriages?

- How the cultural stigma attached with inter-tribal marriages encourages the forced marriages?

- How traditions and cultural practices play key role in providing sanctions for the forced marriages and sustaining this behavior among rural communities in Sindh?

- What should be done to decrease the instances of forced marriages among the rural communities of Sindh?

In this study the phenomenon of forced marriages in rural Sindh are studied in a qualitative desk research using the four selected case studies. The case study research method is used to achieve a comprehensive understanding of the phenomenon and see how exactly the taboo against inter-tribal marriages influences forced marriages in real situations. The primary sources like original legal documents and official reports and secondary sources like research studies, NGO reports, magazines, newspapers etc are used for the data collection. The participant observation method is also used in two of the four selected case studies as they are reported from the personal observation of the author.

\section{The Right to Marry in International Law, the Pakistani law and Shariah (Islamic law)}

The right - or the "freedom"- to marry and to establish a family is a fundamental right of the highest order that has been recognized as a basic human right under the international law. Article 16(1) of the Universal Declaration of Human Rights $(\mathrm{UDHR})^{7}$ provides, inter alia, that: "men and women of full age, without any limitation due to race, nationality or religion, have the right to marry and to found a family". The UDHR recognizes the right of marriage and to found a family for every adult male and female and in this regard UDHR does not recognize any limitations on the basis of race, nationality and religion. With regard to the marriage of free consent, UDHR provisions are very clear, Article 16 (2) states, "Marriage shall be entered into only with the free and full consent of the intending spouses". Here words "free and full consent of the intending spouses" leave no room for any doubt and gives every individual a final say in the matter of his own marriage. Pakistan was among those 48 states which adopted the Universal Declaration of Human Rights on 10th of December $1948 .^{8}$ 
Article 10(1) of the United Nations International Covenant on Economic, Social and Cultural Rights (ICESCR) reiterates what is already stated by the UDHR article 16(2), whereby "marriage must be entered into with the free consent of the intending spouses." Pakistan signed ICESCR on November 3, 2004 though ratification still has to come ${ }^{9}$. The important distinction between UDHR and ICESCR is that UDHR is not a legally binding document where as ICESCR is a binding treaty document along with International Covenant on Civil and Political Rights (ICCPR). With regard to the Marriage of free consent the language used in Article 23 (3) of ICCPR is quite similar to the UDHR Article 16 (2), "No Marriage shall be entered into without the free and full consent of the intending spouses". The International Covenant on Civil and Political Rights (ICCPR) is neither signed nor ratified by Pakistani government ${ }^{10}$.

Pakistan also ratified The Convention on the Elimination of All Forms of Discrimination against Women (CEDAW) on 12th March $1996^{11}$ during the rule of female Prime Minister Benazir Bhutto with a reservation that "accession to the Convention is subject to the provisions of the national Constitution". CEDAW bounds the member states to give equal rights to women in all matters of family life and marriage. CEDAW Article 16 states, "States Parties shall take all appropriate measures to eliminate discrimination against women in all matters relating to marriage and family relations and in particular shall ensure, on a basis of equality of men and women: (a) The same right to enter into marriage; (b) The same right freely to choose a spouse and to enter into marriage only with their free and full consent"12. CEDAW puts even more emphasis on right to marry of free consent by adding the word "only" which totally excludes all kinds of forced marriages for women. Pakistan being one of the signatories, government is legally bound to stop any forced marriages of Pakistani women.

The local Pakistani law regarding marriage is somewhat confusing. The legal system in Pakistan is a mixture of English common law and Islamic law (Shariah). The former is more influential in commercial law while the latter is more influential in personal status and family laws. The Personal Law (includes family law) applies on every individual according to the personal faith and particular school of Islamic jurisprudence (Shariah) he/she follows. The majority of Pakistanis follow the Hanafi ${ }^{13}$ School of fiqah ${ }^{14}$ (Hanafi Sunni) and there is also a sizeable minority of fiqah-e-Jaafria ${ }^{15}$ (Shia). The West Pakistan Muslim Personal Law Application Act 1962 directs the application of Muslim personal law, notwithstanding local customs or usage, to all questions of personal status and succession where the parties are Muslims. This clearly means that Muslim Personal law has precedence over local customs and usage. Though we shall see subsequently how local customs and usage play a decisive role in most of the cases. 
According to all fiqahs a Muslim woman is allowed to marry of her free will and her consent is considered compulsory at the time of the marriage. But there has been confusion as to whether Wali's (parent or guardian) consent was an essential requirement for validity of the marriage contract for a Muslim woman? According to the Hanafi School, an adult woman may contract her marriage without a Wali, but the influence of local custom often plays the decisive role. The Lahore High Court (LHC), headed by Justice Khalilur Rehman Khan, sparked a controversy in 1997 by barring Saima Waheed and Shabina Zafar (two different cases) from marrying of their own free will without the consent of Wali (Moosa, 1996-7). Appeals against the LHC decisions were pending in Supreme Court since 1997. This issue was finally settled by the judgment in these two different cases involving Saima Waheed and Shabina Zafar by the Supreme Court (the apex court) of Pakistan on $19^{\text {th }}$ December $2003^{16}$. The Supreme Court ruled that adult Muslim girls were free to marry of their own free will, adding they did not need to seek the consent of their Wali (guardian) or other relatives.

Pakistani laws regarding forced marriages became more clear in 2011, when the parliament passed "The Prevention of Anti-Women Practices Act 2011" which not only prohibited all forms of the forced marriages but also declared local customs like the marriages with Quran and different forms of compensation marriage agreements like badla-e-sulh, sang-chatti, vani and swara as punishable offences under the Pakistani criminal law ${ }^{17}$. The wording of the law is very clear in declaring all forms of forced marriages in Pakistan, "Whoever coerces or in any manner whatsoever compels a woman to enter into marriage shall be punished with imprisonment" for maximum seven years and minimum three years if found guilty" ${ }^{\prime 8}$. But local customs and tribal rules which are also described as the customary law still hold supreme in most of the cases s as state laws in Pakistan come into action rarely (Rahman, 1968). Hence national laws in Pakistan are no more a hurdle, however, the non-implementation of those laws and preponderance of the customary laws over national Pakistani laws is still a problem.

\section{Forced Marriages and the Taboo Attached with Inter-Tribal Marriages in Rural Sindh}

It is observed in previous section that International Law, Shariah law and Pakistani laws especially after 2011 Anti-Women Practices Act prohibit forced marriages in its all forms. However, the 2011 Act is not enforced by the law enforcement agencies in its true spirit in the presence of clear legal injunctions. It is difficult to find any statistical data on forced marriages in rural Sindh and other parts of Pakistan. But in last two decades or so the cases of love couples leaving their homes have multiplied with every passing year, as revealed by the ever increasing reports in local Urdu and Sindhi press. 
The data on honour killings and couples leaving their homes to save their lives might give some idea about the magnitude of forced marriages but relying on that data would be hugely misleading because it would exclude the silent majority in rural areas of Sindh who are accepting this as their fate and do not have the courage to speak out. In rural Sindh although it is hard to find a proper statistical date but one can find all types of forced marriages like marriages with Quran, child marriages, exchange marriages, consanguineal marriages and compensation marriages in abundance. And what provides social acceptance and an indemnity to the culprits of all those criminals of forced marriages, are the local customs and practices.

Among cultural practices, the worst among all is the practice of disallowing intertribal marriages in the rural areas of Sindh. Allowing only intra-tribal marriages and strictly disallowing inter-tribal marriages is a common practice among most of the tribes and clans in rural Sindh. In fact, it is this cultural practice which plays major role behind all other forms of forced marriages like marriages with Quran, child marriages, exchange marriages and consanguineal marriages. The limitation of intra-tribal marriages limits the choices for the groom and the bride and makes it so difficult for them to find their proper match. They are left with only one choice-either to accept it as their fate or run away with their bride or groom from the other tribe. And it is running away with a man or a girl from other tribe which causes the honour killings in extreme cases. On the other hand sometimes to keep marriages within their extended families and tribes parents force their children for marriage with Quran, consanguineal marriage or exchange marriage.

Resistance to forced marriages has gradually increased during the last two decades in rural Sindh which is evident from the increasing reports in local Sindhi newspapers about premi jora, the love couples leaving their homes and seeking help from Human Rights organizations and newspaper offices to rescue their lives. There are a few high profile cases in this regard such as Shaista Almani case and Shazia Khaskheli case which got the attention of national press for several months in 2004-05 and many other low profile cases such as the case of then local counsellor of a Union Council in the Khairpur district, Noor Khatoon Shar, could get local attention only. Still there are other cases in vast majority which are not reported because families are able to suppress them under the carpet by forcing the couples to surrender for the sake of family honour and prestige.

It is strange that even local and international human rights organizations working in Sindh and local NGO's are not taking full account of this situation. Except one study by Sarah Zaman of Aurat Foundation no attempt is made to do separate systematic studies on the subject of forced marriages in Pakistan (Zaman, 2014b). Even Zaman (2014b) based her study on two urban districts from Sindh, the 
Karachi and the Hyderabad districts, and completely neglected the rural areas of Sindh. It is even more surprising that the annual reports of the Human Rights Commission of Pakistan and the Amnesty International rarely discuss forced marriages as a separate issue. However, some stories and reports can be found on honour killings and compensation marriages like swara, vani, sang-chatti etc but forced marriages as a whole are not discussed.

\section{The Four Selected Case Studies from Rural Sindh}

Before going into a more analytical discussion it would be good to look at a few selected case studies here to get the sense of the alarming nature of the problem. The first two cases are based in a rural background of Sindh province where Sardari system and tribal clans are very strong. It is already pointed out in this paper that inter-tribal marriages are not allowed by most of the tribes and castes in Sindh. However, especially in Baloch tribes like Almani tribe where Sardari system $^{19}$ is very strong, marriage out of the tribe is considered not just a taboo but also a crime punishable to death.

Shaista Almani, a 23-year-old private school teacher was declared $\mathrm{Kari}^{20}$ (impure) by the Almani tribe after she married Balakh Sher alias Qadir Baksh Mahar of the opponent Mahar tribe out of her own will on June 1, 2003 in Pano Aqil, district Ghotki Sindh $^{21}$. Shaista met Balakh Sher, some time back and they developed a liking for each other. Later, Balakh Sher sent a marriage proposal to her parents, to which her parents initially showed reluctance but later gave a green signal to ${ }^{22}$.

Her father, Himmat Ali Almani, forgave Shaista for marrying of her free will, but the Almani sardar ${ }^{23}$ was not willing to accept this marriage. Fearing for their lives, the legally married couple fled up North where friends gave them shelter but tribal predators tracked them down. They forcibly brought back the couple to Ghotki on October 25 to face a tribal jirga (Agha, 2004). After severe tribal pressure Mr. Mahar divorced Shaista, under the jirga (tribal) verdict ${ }^{24}$. Shaista was declared 'Kari' and faced possible death under jirga law for marrying of her own free will. Tribal chiefs assigned dozens of armed tribesmen from their area to kill her according to their "Kari" tradition (Agha, 2004). Shaista became shelter less, and her life came under direct threat just for marrying of her own will. Shaista took the bold step of taking the issue to the media and higher authorities.

Then Human Rights groups became active and this case became one of the most high profile cases in the recent history. Even then President Musharraf was obliged to interfere and then Chief Minister of Sindh Ali Mohammad Mahar, the real brother of the Sardar of Mahar tribe came under direct threat to be removed from his office. The Human Rights Commission of Pakistan, the Women's Action Forum and the Aurat Foundation together filed a constitutional petition before the 
Sukkur Bench of the High Court of Sindh (874/03) against the Federation of Pakistan and 15 others asking that Shaista be given protection and saved from being killed (Cowasjee, 2003). Finally the court decided that the divorce between Shaista and Balkh Sher was null and void according to the Shariah law because it was taken by force and the proper method of divorce was not followed, therefore, their marriage contract was intact (Yousif, 2010). Notwithstanding the court decision Shaista and Balkh Sher fearing death by some furious tribal group or an individual fled to Europe to save their lives.

In practice local customs and biradari (small unit of community) decisions are stronger than the state laws and often law enforcement agencies either play the role of a silent spectator or even are found in complicity with the culprits. In such a story, Shazia Khaskheli, and Mohammad Hassan Solangi, a young, recently married couple, were brutally murdered in Sanghar, Sindh by their tribesmen. The daughter of a bank officer and member of the Khaskheli tribe, Shazia, an intermediate student, left her home on September 27 and eloped with Mohammad Hassan Solangi, the driver at a neighbor's house (Shah, 2003a). The Solangis, who are also called 'Machhi' - fish traders - are perceived as a lower caste by the Khaskhelis. A witness recounts: "The tribesmen cut Hassan with knives and poured salt and chilli powder into the wounds. Then they broke his arms and legs (Shah, 2003a)." Shazia meanwhile, was given a choice. She was told if she stated she had been kidnapped by Hassan, she would be allowed to go. However, she refused and was also tortured, as a result of which she was blinded in one eye (Shah, 2003b). While the couple was being brutalized, a huge crowd had collected outside the house. One of the eye-witness told reporters, "It was like a big mela (means fair) outside the house. Everyone knew what was happening, but no one dared to intervene" (Shah, 2003a). According to the news reports there was little doubt that the police were aware of what was happening and, by all accounts, they did nothing to prevent the murder.

In such cases sometimes when even family members do not have a problem, still tribesmen do not spare the couple and kill them for their so-called 'honour'. Like in Shazia Khaskheli case her parents were willing to accept her marriage. Shazia's father had told Dawn that he wanted his daughter to return home so that he could forgive her but tribesmen killed her "to save the family's honour" 25 . However, in some other cases of honour-killing even brothers and fathers are found killing their daughters and sisters.

Most of these cases which are reported in the media and by the human rights groups involve communities where tribal conventions are very strong. But this does not mean forced marriages are restricted to the tribal communities only. The honour killings, child marriages and marriages with Quran may be restricted only to limited families of tribal backgrounds; however, forced marriages of mild 
nature are a common feature in rural Sindh. Even educated families with rural background settled in towns and bigger cities have the tendencies to force specially their women to marry of parents' choice. Rarely do such cases get reported because those involved do not allow situation to reach that point. Girls are often pressurized in different ways in the name of honour and prestige of family to give the sacrifice and marry silently.

Here are two stories from Khairpur, Sindh that would never reach to the media and human rights groups because they are ordinary stories involving lesser violence. But they speak to a more common truth which is a routine affair in most of the areas in rural Sindh. These two stories came across to my knowledge directly from the mouth of the characters involved in stories. These stories show the depth of the problem that why in Sindh parents do not allow marriages of their daughter's choice and how cultural customs and practices leave little room for the parents to accept the choice of their daughters especially when it comes to the inter-tribal marriages.

In one case a college lecturer from Khaskheli tribe fell in love with a girl from a Sindhi Baluch ${ }^{26}$ tribe belonging to a very educated and modern family. The girl forced him to arrange a court marriage because she feared that her father would not allow their marriage and would force her to marry her cousin as soon as he knew about their relationship. She really did not like her cousin and considered him a bad character. Infact her marriage was already arranged with that cousin when she was only five years old $^{27}$. When the girl's father discovered their marriage, he became furious and physically tortured her by beating to force her to seek divorce from her husband. When she refused, the girl was taken to a trusted friend in captivity so that her legal husband should not reach her. After a few years of captivity she was brought to the district court where she sought divorce from the same husband whom she had earlier pressed to marry her. Ultimately, the divorce was sanctioned by the court despite her husband's pleas for her forceful captivity.

In another story a middle class boy from one tribe fell in love with a girl from the other tribe whom he used to teach tuition. The girl belonged to a very orthodox religious family. When he expressed his love for the girl she told him that she also liked him but he must convince her parents because she cannot even think of disobeying the parents. When he sent a formal proposal of his marriage through his family, the girl's parents asked them to wait as they needed time to decide. But boy did not receive any clear cut response for more than a year. Later on at boy's consistent persistence the girl's father told him that he liked the boy's character and he acknowledged the fact that his daughter would not be more suitably matched but he refused on the grounds that his eldest son did not like the idea 
because he feared that people would accuse the girl of having a love affair with her mentor from the other tribe.

The above two stories are not just two specific case studies; rather they provide a window into what happens in normal circumstances when a couple wants to marry out of their tribe in rural Sindh background. They depict a typical mindset in rural Sindh which considers inter-tribal marriages a dishonour for the tribe and a girl's love for a boy as something bad and disrespectful for the girl's family. This mindset and the traditions and the cultural practices which protect and justify forced marriages in the name of tribal and family honour are the problem.

\section{The Cultural Taboo Attached with Intra-Tribal Marriages is the Culprit}

It is obvious from above selected case studies that because of the taboo attached with inter-tribal marriages, forced marriages are a common feature in the settings of rural background in Sindh. Moreover, the complexity of the problem is also clear because it has its legal, cultural and religious dimensions as well that make it sensitive and emotional issue for the communities involved because people tend to be very sensitive about their perceptions of culture and religion. Religion does not provide the sanctions for the forced marriages but it is also used as a tool to justify the forced marriages.

The Pakistan Peoples Party's (PPP) parliamentarian, Aitzaz Ahsan once told the parliament in July 2004 that honour-killing might have existed for centuries but the incidence of such murders increased after military ruler Gen Mohammad Ziaul Haq enforced the Qisas and Diyat Ordinance in 1979 which provided a pardon for such actions by the heirs of a victim ${ }^{28}$. Pushing for his bill on declaring the honour-killing a murder, Mr. Ahsan had argued that the increase in the incidence of honour-killing was facilitated by the ease with which the culprits used to escape the punishment. He said, "Justifying the brutal crime as being rooted in archaic customs, they are forgiven in out-of-court processes that are recognized by law. Thus (a) heinous murder goes unpunished."29 No doubt failure in maintaining the writ of law by the state authorities forces people to look for extra-legal options. When urgent legal remedies are not available through courts, people tend to rely more on local informal justice forums like jirgas and panchayats.

After the passage of the Prevention of Anti Women Practices (Criminal Law Amendment) Act 2011, now at least a specific law exists in Pakistan which declares all forms of forced marriages as criminal act. But the important question is whether forced marriages can be stopped by just declaring them illegal and enforcing the law? It may to some extent reduce the number of extreme cases. In this regard a very important comment was made by a simple villager from Rato 
Dero Sindh in his interview with the BBC reporter during a short film on Karian jo Qabrustan ${ }^{30}$ (the graveyard of women killed in honour killings) that number of such events did not decline even during the days of British rule when Law was strictly enforced and perpetrators were punished severely ${ }^{31}$. This can also be understood from the fact that in many cases culprits kill their close relatives for the sake of honour and then bravely present themselves to the police. They never regret on their actions and for them legal punishment counts little.

More importantly no law or government can stop whatever happens inside the homes. Under what law can a father be punished who successfully forces his daughter to marry for his business gain or personal ego and honour? Mr. Aitzaz Ahsan is right when he says, justifying brutal crime in archaic custom is wrong but he cannot deny the fact, that brutal crime is deeply rooted in local custom and culture. The custom like Danwan which is mentioned in the very beginning of this paper goes unnoticed because no one in the community questions its bias against women. But my then three years old daughter was able to notice the fact that she could not have the same ritual when other boys of her age had the same.

One cannot deny the fact that the fabric of culture in rural Sindh is built in such a manner which promotes and protects these brutal crimes against humanity and specially women. A culture which considers a woman more an object of honour and respect for a man than a human being with same sensations and feelings like a man possess cannot give her right to marry of free consent.

This is true for an average family in the context of rural Sindh that when a girl member of the family chooses someone from outside the tribe as her bride, in such cases male members of the family feels that their honour, respect and social status is threatened. And worse is the fact that this threat is not imaginary but it is real because society behaves in this way. Everyone looks down upon the family of girl and they suddenly become an outcast among their own people. It is a social crime in rural Sindh to be a father of a daughter who has married out of her tribe.

The most important question still remains unanswered that who is responsible then for forced marriages in Sindh? The government and the police, who are not fulfilling their basic duty of enforcing the rule of law or the judiciary which has failed to judiciously, punish the culprits? Or those fathers and brothers who kill their daughters and sisters opting for inter-tribal marriages, based on their flawed perceptions of the honour and self-respect? Or that society and culture which makes those fathers and brothers feel outcast among their own people? May be all these factors play their part but the importance of the cultural aspect cannot be over-emphasized here. 


\section{What can be done?}

What is really missing in the whole discourse is the fact that no one is challenging the traditions and cultural practices that promote forced marriages. The human rights groups rightly blame government for its inaction and if issue goes to the level of killing the couples then the culprits are now seen as criminals by the larger section of the society. However, still tribal communities consider marriage outside the tribe and clan a good reason for killing the couples, while others force their daughters and sisters to marry within tribe. But no one among community, human rights groups and the civil society takes a stand against the ban on intertribal marriages and cultural practices that give no breathing space to the parents of the girls who choose to marry out of their tribes.

If ban on inter-tribal marriages had been a cultural practice in a community it does not mean that community will not allow inter-tribal marriages forever. Living cultures always change with the time. They infuse good things and leave out bad things. The culture where women are considered merely an object of honour has to undergo a change if forced marriages are to be stopped. The society has to accept the fact that marriage is a basic right of an individual and he/she must have the final say in such an important matter of his/her life.

To transform the traditions and cultural practices one need to at first challenge them. Just exposing the culprits and campaigning for their punishment according to the law of land is not enough. The thinking of the people has to undergo a change. The social behaviour which considers inter-tribal marriages a social crime needs to be discouraged by the civil society. An open debate on print and electronic media challenging such a behaviour will give the couples more courage and it will give common folk and parents a food for thought. The love couples, like Shaista- Balkh Sher need not to fled the country, it is the responsibility of the government and the civil society to create a space for them within their own communities. Their presence among their people makes a difference.

The cultural practices, like giving preference to the birth of a boy child and considering the birth of a girl child something not good for the family, need to be discouraged by the civil society. The anti-feminist cultural behaviour and rituals like Danwan need to be challenged in films, TV plays, print and electronic media, literature and day-to-day affairs of life.

\section{Conclusions}

During the course of this paper it is observed that the problem of forced marriages in rural Sindh is closely connected with the taboo attached with inter-tribal marriages among the rural communities. Moreover, it is also related with the 
general status of women and their position and empowerment among rural communities in Sindh. The male members among tribal communities also become victims of forced marriages at times but for women the situation is worst. It is acute in small villages and tribal cultures where women are powerless and they are merely considered an object of honour for male members of the family. However, forced marriages are also common in bigger towns and among the rural migrants of even larger cities like Khairpur, Sukkur and Hyderabad.

In spite of the fact that every Bollywood ${ }^{32}$ movie and every Pakistani TV drama revolves around a love story, still love marriage has not gained a social acceptance in the society. Love marriage is considered something bad and disrespectful for the family of girl specially. Every tribe and clan would appreciate their man bringing a woman from other tribes and tell the stories of the valour of that man with pride. But a story of their woman going with a man of other tribe becomes a shameful story for the tribe. The tribes and families use to taunt each other with those stories when they have small matters against each other.

\section{End Notes}

1. See FMU statistics for 2012 and 2013. https://www.gov.uk/government/ uploads/system/uploads/attachment_data/file/141823/Stats_2012.pdf and https://www.gov.uk/government/uploads/system/uploads/attachment_data/file /291855/FMU_2013_statistics.pdf (accessed on 16/01/16)

2. See Forced Marriage (civil protection) act 2007 http://www.legislation.gov. uk/ukpga/2007/20/introduction (accessed on January 13, 2016)

3. Daily Independent, June 16, 2014, http://www.independent.co.uk/news/uk/ home-news/new-law-against-forced-marriage-takes-effect-9539097.html (accessed on January 13, 2016)

4. See the text of the Anti-Women Practices Act 2011 http://www.na.gov.pk/ uploads/documents/1329729400_262.pdf (accessed on 15/01/16)

5. 1261 women kidnapped in Sindh for forced marriages in 2014, (2014) Dawn, December 31. http://www.dawn.com/news/1154059 (accessed on 15/01/2016).

6. Shahid Hussain, 'Most forced conversions in Sindh go unreported: study' (2015) The News, May 20. http://www.thenews.com.pk/print/41418-mostforced-conversions-in-sindh-go-unreported-study (accessed on 15/01/2016)

7. See the document of the Universal Declaration of Human Rights. http://www.un.org/Overview/rights.html (accessed on 15/01/2016)

8. UDHR Members list http://www.humanrightsandtolerance.org/udhrmembers.html (accessed on 15/04/2006)

9. United Nations International Covenant on Economic, Social and Cultural Rights (ICESCR) ratification http://www.ohchr.org/english/countries/ ratification/3.htm (accessed on 15/04/2006) 
10. Ibid.

11. Convention on the Elimination of All Forms of Discrimination against Women (CEDAW) ratification https://treaties.un.org/Pages/ViewDetails. aspx? src $=$ TREATY\&mtdsg_no $=I V-8 \&$ chapter $=4 \&$ lang $=$ en $\quad($ accessed on 16/01/2016)

12. See CEDAW article 16 http://www.un.org/womenwatch/daw/cedaw/text/ econvention.htm\#article16 (accessed on 16/01/2016)

13. Hanafi is one of the four schools (madhabs) of Fiqh or religious law within Sunni Islam. Founded by Imam Abu Hanifa, it is considered to be the school most open to modern ideas (Wikipedia).

14. Islamic jurisprudence, Fiqh (in Arabic and Persian) is made up of the rulings of Islamic jurists to direct the lives of the Muslim faithful. There were four dominant Sunni schools or maddhab of fiqh (from Wikidedia).

15. The Jaferi school (Iran, Iraq, and parts of Afghanistan) is more associated with Shia Islam.

16. Girls can marry of their own will: SC' (2003) Dawn, December 20. http://www.dawn.com/news/130393/girls-can-marry-of-their-own-will-sc (accessed on 17/01/2016)

17. NA passes Prevention of Anti-Women Practices Bill', (2011) Dawn, November 15. http://www.dawn.com/news/673444/na-passes-prevention-ofanti-women-practices-bill (accessed on 15/01/2016)

18. See the text of the Anti-Women Practices Act 2011 http://www.na.gov.pk/ uploads/documents/1329729400_262.pdf (accessed on 15/01/16)

19. Sardar is a chief or head of the tribe and he is considered to have the sovereignty over the people of his tribe. Sardari system is a kind of law which is based on the traditions and local customs of the community involved. Sardar of the tribe or community decide the cases ranging from family disputes to murder without taking recourse to the normal law of the state. It is practiced in the rural areas of Pakistan in different forms

20. In Southern province Sindh, a kari (literally a 'black woman') and a karo ('a black man') are hacked to pieces by axe and hatchets, often with the complicity of the community for their perceived illegal sexual activity and in many cases like the one of Shaista even marrying out of tribe is considered good enough reason to be declared kari. This thing happens in other parts of Pakistan as well but with different names like Siyah-Kari and honour-killing.

21. Razzak Abro (2004) 'Almani tribal chief insists Shaista isn't 'kari'. Daily Times, January 16.

22. Hassan Mansoor (2004) 'Shaista's story is Sindh's shame'. The Friday Times, January 16-22. https:/hasanmansoor.wordpress.com/2015/10/21/shaistasstory-is-sindhs-shame/ (accessed on 17/01/2016)

23. Sardar is the tribal head or chieftain of a tribe or clan. Sardars possess political and social authority and they control the lives of their tribesmen in a big way. 
District Ghotki is dominated by three big Sardars belonging to Mahar, Almani and Lund tribes.

24. The Jirga is a tribal assembly where "respected", "old" and "wise" men of the tribe or community decide the cases ranging from family disputes to murder without taking recourse to the normal law of the state. It is practiced in the rural areas of Pakistan in different forms.

25. Kari (black woman) is generally used for a girl who has extra-marital relations with a man but in many cases even girls marrying of their own choice are declared as kari in the tribal informal justice system.

26. In Sindh there are several Baluch tribes which migrated to Sindh a few centuries back and now even can not speak Baluchi but still take pride in their Baluch traditions and customs.

27. Such marriages are very common in the rural areas of Pakistan where parents arrange the marriage of their siblings at very young age and sometimes even when kids are still in the womb of their mothers, the marriages are arranged.

28. This is a short video on "The graveyard of Kari", where reporter visits a few centuries old graveyard in Rato Dero Sindh, which was specific only for "kari" (the woman killed in honour killing) because people did not allow "kari" to be buried in a regular graveyard.

29. http://www.bbc.co.uk/urdu/interactivity/blog/story/2005/09/050922_kari_grav es_ms.shtml (accessed on May 31, 2006)

30. This is a short video on "The graveyard of Kari", where reporter visits a few centuries old graveyard in Rato Dero Sindh, which was specific only for "kari" (the woman killed in honour killing) because people did not allow "kari" to be buried in a regular graveyard.

31. http://www.bbc.co.uk/urdu/interactivity/blog/story/2005/09/050922_kari_grav es_ms.shtml (accessed on May 31, 2006)

32. The term used for Indian film industry. Indian films are seen in every Pakistani home more than the Pakistani films.

\section{References}

Agha, M. (2004). Tribal Culture in Pakistan \& The Victims of Love, Social Pages, No. 107, vol.9.

Caroll, L (1998). Arranged Marriages: Law, Custom, and the Muslim Girl in the U.K.' Women Living Under Muslim Laws Dossier (20).

Chaudhary, M.A. (2014). Interpreting Honour Crimes in Pakistan: The Case Studies of the Pukhtun and the Punjabi Societies. Anthropos, vol.109, pp. $196-206$. 
Chaudhary, M.A. (2011). A Woman's Marriage to Quran: An Anthropological Perspective from Pakistan, Anthropos, vol.106:1, pp.1-12.

Cowasjee, A. (2003). Archenemies of Mankind, Dawn, December 21.

Foreign and Commonwealth Office and Department of Health. (2003). Young People Facing Forced Marriage. Guidelines for social workers. London: Community Liason Unit, Foreign and Commonwealth Office.

Gangoli, G, Razak, A. \& McCarry, M. (2006). Forced Marriage and Domestic Violence among South Asian Communities in North East England, School for Policy Studies, University of Bristol and Northern Rock Foundation.

Home Office (2006). Forced Marriage: The Risk Factors and the Effect of Raising the Minimum Age for a Sponsor, and of Leave to Enter The UK as a Spouse” (SRG/05/037). London: Home Office.

Hossain, S. (2000). The Abduction and Forced Marriage of Women as a Violation of Women's Human Rights. Paper from Conference on Forced Marriage, Newham Council, UK, February 25.

INTERIGHTS, Ain O Sailish Kendra (ASK) and Shirkat Gah (2000). Home Office Working Group on Information Gathering on Forced Marriages, London: Home Office.

Khan, H.G.A., Sultana, A. \& Awais-e-Siraj, (2011). Consanguinal Marriages in Pakistan: A Tradition or a Cultural Politics and Possible Management Measures, Canadian Social Science, vol.7:1, pp.119-123.

Khan, T.S. (2006). Beyond Honour: A Historical Materialist Explanation of Honour Related Violence. Islamabad: Oxford University Press.

Knudsen, A. (2004). License to kill: Honour killings in Pakistan. Postterminalen, Norway: Chr. Michelsen Institute.

Masihuddin, H. \& Minallah S. (2012). Compensation Marriages: Swara, Vanni, Sang Chatti, Bhan/Irjaai', Islamabad: UN Women.

Moosa, E. (1996-97). Is an Adult Muslim Woman Sui Juris? Some Reflections on the Concept of "Consent in Marriage" without a Wali (with Particular Reference to the Saima Waheed Case). Yearbook of Islamic and Middle Eastern Law, Volume 3. 
Movement for Solidarity and Peace (MSP). (2014). Report on Forced Marriages \& Forced Conversions in the Christian Community of Pakistan. Islamabad: Movement for Solidarity and Peace.

Naveed, S. \& Butt, K.M. (2015). Causes and Consequences of Child Marriages in South Asia: Pakistan's Perspective. South Asian Studies: A Research Journal of South Asian Studies, vol.30:2, July - December, pp. 161 - 175.

Rahman, H.A. (1968). Customary Law in Pakistan, In David C. Buxbaum (ed.) Family Law and Customary Law in Asia: A Contemporary Legal Perspective. The Hague: Springer Science+Business Media.

Shah, Z. (2003). Till Death Do us Apart, Newsline Karachi, November.

Shah, Z. (2003). In the Name of Love, Newsline Karachi, November.

Samad, A.Y. \& Eades, J. (2002). Community Perceptions of Forced Marriage. London: Community Liaison Unit, The Foreign and Commonwealth Office, United Kingdom.

Siddiqui, H. (2002). Forced Marriages: An Abuse of Women's Human Rights, Rights of Women Bulletin Spring 2002: 2-4.

Uddin, B. \& Ahmed, L. (2000). A Choice by Right: The Report of the Working Group on Forced Marriage, London: Home Office, Communications Directorate.

Yousuf, N. (2010). Shaista Almani's Marriage: Political Noise and Silence for Political Gains', January 05, 2010, http://psjg.bizcue.com/shaista_Almani.htm (accessed on 18/01/2016)

Zaman, M. (2011). Exchange Marriages in South Punjab, Pakistan: A Sociological Analysis of Kinship Structure, Agency, and Symbolic Culture'. Frankfurt (M)/ Berlin: Peter Lang Publisher.

Zaman, M. (2012). Exchange Marriage System and Muslim Family Laws in Pakistan'. Pakistan Journal of History and Culture, vol.XXXIII:I.

Zaman, M. (2014a). Exchange Marriages in a Community of Pakistan: Adequate Social Exchange. The Family Journal (Sage), vol.22:1, pp.69-77.

Zaman, S. (2014b). Forced Marriages and Inheritance Deprivation in Pakistan: A Research Study Exploring Substantive and Structural Gaps in the 
Implementation of Prevention of Anti-Women Practices [Criminal Law Amendment] Act, 2011. Karachi: Aurat Publication and Information Service Foundation.

Dr. Saeed Ahmed Rid is an Assistant Professor in the National Institute of Pakistan Studies, Quaid-i-Azam University, Islamabad. 